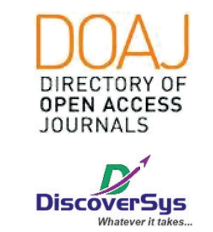

Published by DiscoverSys

\section{Gambaran persepsi ibu terhadap obesitas pada anak usia sekolah dasar di Kecamatan Canggu, Kabupaten Badung, Bali tahun 2018}

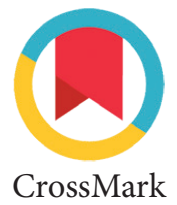

\author{
Putu Eksa Bidja Yudha Putri, ${ }^{*}$ Komang Ayu Kartika Sari, ${ }^{2}$ Luh Putu Ariastuti ${ }^{2}$
}

\title{
ABSTRACT
}

Introduction: Obesity is a condition where there is excess body fat accumulation so that a person's weight is far above normal. The current problem of overnutrition in Indonesia must get attention; the prevalence of obesity in children in Indonesia continues to increase in 2007 by $7.95 \%$ and increased to $18.8 \%$ in 2013 .

Method: This study is a descriptive study with a cross sectional study design that aims to describe mothers' perceptions of obesity in children after primary school. The samples from this study were
92 respondents, with random sampling technique and the research using a questionnaire measuring instrument.

Result: Mothers who have a positive perception of obesity in children as much as $56.5 \%$ while mothers who have a negative perception of obesity in children as much as $43.5 \%$.

Conclusion: Based on these results it can be concluded that there are still many mothers who consider that obesity in children is not a problem for children's health

Keywords: Elementary School Children, Obesity, Perception

Cite This Article: Putri, P.E.B.Y., Sari, K.A.K., Ariastuti, L.P. 2019. Gambaran persepsi ibu terhadap obesitas pada anak usia sekolah dasar di Kecamatan Canggu, Kabupaten Badung, Bali tahun 2018. Intisari Sains Medis 10(3): 737-740. D0l: 10.15562/ism.v10i3.420

\section{ABSTRAK}

Latar Belakang: Obesitas adalah suatu keadaan terjadinya penumpukan lemak tubuh yang berlebih, sehingga berat badan seseorang jauh melebihi norma. Pemasalahan gizi lebih di Indonesia harus mendapatkan perhatian, prevalensi obesitas pada anak di indonesia terus meningkat. Pada tahun 2007 sebesar 7,95\%, di tahun 2013 meningkat menjadi 18,8\%.

Metode: Penelitian ini merupakan penelitian deskrtitifdengan rancangan penelitian cross sectional yang bertujuan untuk menggambarkan persepsi ibu terhadap obesitas pada anak usai sekolah dasar. Sempel dari penelitian ini adalah sebanyak 92 responden, dengan teknik pengambilan sempel random sampling dan penelitian ini menggunakan alat ukur kuesioner Hasil: Ibu yang memiliki persepsi positif terhadap obesitas pada anak sebanyak 56,5\% sedangkan ibu yang memiliki persepsi negatif terhadap obesitas pada anak sebanyak $43,5 \%$

Simpulan: Masih banyak ibu yang menganggap bahwa obesitas pada anak bukan maslah bagi ksehatan anak.
'Program Studi Pendidikan Dokter ${ }^{2}$ Departemen IImu Kedokteran Komunitas/llmu Kedokteran Pencegahan

Fakultas Kedokteran Universitas Udayana

*Korespondensi:

Putu Eksa Bidja Yudha Putri, Program Studi Pendidikan Dokter eksabidja26@gmail.com

Diterima: 04-03-2019

Disetujui: $15-07-2018$

Diterbitkan: 01-12-2019
Kata kunci: Anak Sekolah Dasar, Obesitas, Persepsi lbu

Cite Pasal Ini: Putri, P.E.B.Y., Sari, K.A.K., Ariastuti, L.P. 2019. Gambaran persepsi ibu terhadap obesitas pada anak usia sekolah dasar di Kecamatan Canggu, Kabupaten Badung, Bali tahun 2018. Intisari Sains Medis 10(3): 737-740. D0I: 10.15562/ism.v10i3.420

\section{PENDAHULUAN}

Indonesia seang memasuki permasalahan gizi ganda, karena masalah gizi kurang masih belum teratasi sepenuhnya, sementara kini sudah muncul masalah gizi berlebih. Kelebihan gizi dapat menyebabkan keadaan yang kita sebut dengan obseitas. Obesitas dapat terjadi pada usia anak-anak hingga usia dewasa. ${ }^{1}$

Pemasalahan gizi berlebih di Indonesia harus mendapatkan perhatian. Angka prevalensi gizi lebih di indonesia pada tahun 2007 sebesar 7,95\%, di tahun 2013 meningkat menjadi 18,8\%. Permasalah obesitas juga sedang dihadapi oleh negara-negara berkembang lainnya, seperti angka prevalensi obesitas Thailand yang meningkat dalam waktu dua tahun dari $12,2 \%$ menjadi 15,6\%, selain itu angka prevalensi obesitas pada anak-anak Singapura pada tahun 2000 meningkat dari 9\% menjadi 19\%. ${ }^{2} \mathrm{Di}$ Indonesia pada tahun 2013, 15 provinsi memiliki angka gizi lebih di atas angka nasional, salah satunya adalah provinsi Bali. ${ }^{3}$ Berdasarkan data Riskesdas (2013), prevalensi obesitas pada anak di Kabupaten Badung sebesar 4,6\%. ${ }^{3}$

Banyak orang tua yang salah mengklasifikasi berat badan anaknya. orang tua mungkin menganggap berat badan anaknya normal, namun setelah dilakukan pemeriksaan, ternyata anak mereka 
mengalami kelebihan berat badan. ${ }^{4}$ Masyarakat masih meyakini persepsi lama, bahwa anak gemuk adalah anak yang sehat. ${ }^{5}$ Penelitian di Iran menunjukan banyak ibu yang tidak mengetahui tentang kesehatan berat badan anak mereka, hal ini menyebabkan ibu gagal mengenali anak mereka sedang mengalami obesitas ${ }^{6}$ Ibu berperan penting dalam pengaruh sumber, keanekaragaman dan kuantitas makanan untuk anak mereka. Obesitas pada anak dipengaruhi oleh konteks kehidupan keluarganya khususnya ibu, hal ini menunjukkan adanya peran keluarga dalam peningkatan prevalensi obesitas pada anak. ${ }^{7,8}$

Menurut penelitian Ingranuridani (2008), ibu yang jarang di rumah atau bekerja di luar rumah memiliki persepsi positif terhadap obesitas pada anak sebanyak $60 \%$ ibu yang jarang di rumah memiliki persepsi bahwa obesitas pada anak bukanlah suatu maslah pada anak, sedangkan ibu yang tidak bekerja mempunyai persepsi negatif terhadap obesitas pada anak sebanyak $40 \%$. Penelitian yang dilakukan oleh Baughcum (2002) menunjukan bahwa ibu dengan pendidikan perguruan tinggi memiliki perespsi negatif terhadap obesitas sebanyak $57,1 \%$ meyakini bahwa obesitas pada anak akan mempengaruhi kesehatan pada anak, sedangkan ibu dengan pendidikan terakhir SMP mempunyai persepsi positif terhadap obesitas sebanyak $52,4 \%$ ibu dengan pendidikan terakhir SMP meyakini bahwa obesitas pada anak tidak memiliki masalah kesehatan yang serius. ${ }^{9}$ Penelitian oleh Ratna Sari (2015), menunjukan bahwa responden dengan usia 20 tahun sampai 40 tahun memiliki persepsi yang positif terhadap obesitas sebanyak $51 \%$, hal ini dimungkinkan karena ibu yang berusia produktif kurang mendapatkan informasi tentang obesitas pada anak sehingga memiliki persepsi obesitas pada anak itu baik, sedangkan responden usia dari 41 tahun sampai 60 tahun sebanyak 76,9\% mempunyai persepsi negatif terdap obesitas. Menurut

Tabel 1 Karakteristik Responden

\begin{tabular}{lc}
\hline Variabel & $\mathbf{n = 9 2}(\mathbf{\%})$ \\
\hline Usia & \\
20-29 Tahun & $6(6,5)$ \\
30-39 Tahun & $58(63,0)$ \\
40-50 Tahun & $28(30,4)$ \\
Pendidikan & \\
Pendidikan dasar & $18(19,6)$ \\
Pendidikan menengah & $54(58,7)$ \\
Pendidikan tinggi & $20(21,7)$ \\
Pekerjaan & \\
Bekerja & $59(64,1)$ \\
Tidak bekerja & $33(35,9)$ \\
\hline
\end{tabular}

Penelitian Admo \& Breet (2014) terlihat bahwa responden yang mempunyai penghasilan tinggi memliki persepsi positif sebanyak $50 \%$, sedangkan responden dengan pendapatan rendah memiiki persepsi negatif sebanyak $54 \% .^{10}$

\section{METODE}

Penelitian ini merupakan penelitian deskriptif dengan desain penelitian cross-sectional (potong lintang) yang bertujuan untuk menggambarkan persepsi ibu terhadap obesitas pada anak usai sekolah dasar. Penelitian ini dilakukan di SD Negri 2 Canggu dan SD Negri 4 Canggu pada bulan September 2018. Sampel penelitian ini adalah ibu dari anak yang bersekolah di SD Negri 2 Canggu dan SD Negri 4 Canggu. Kriteria inklusi adalah ibu Bersedia Menjadi Responden, ibu yang mampu membaca dan menulis. Kriteria ekslusi adalah anak tidak masuk sekolah. 92 responden didapatkan dengan teknik random sampling.

Alat pengumpul data yang digunakan dalam penelitian ini adalah kuesioner. Kuesioner terdiri dari dua bagian. Bagian pertama terdapat data demografi yang berisi tentang usia, status pekerjaan dan pendidikan terakhir. Bagian kedua terdapat pertanyaan positif dan pertanyaan negtif mengenai persepsi ibu terhadap obesitas pada anak usia sekolah dasar dengan menggunakan kuesioner close ended item yaitu, kuesioner dengan memberikan banyak pilihan jawaban. Kuesioner close ended item ini menggunakan skala Likert. Skala Likert ini diberi 4 pilihan jawaban yaitu, sangat setuju, setuju, tidak setuju dan sangat tidak setuju. Data kemudian dianalisis menggunakan bantuan program software (piranti lunak) SPSS.

\section{HASIL}

Berdasarkan karakteristik responden paling banyak dari kelompok usia 30-39 tahun $(63,0 \%)$, dengan pendidikan terakhir paling banyak adalah pendidikan menengah $(58,7 \%)$ lebih banyak responden yang bekerja $(64,1 \%)$ dan lebih banyak responden yang pendapatan $<2.499 .000(67,4 \%)$.

Secara umum responden lebih banyak memiliki persepsi positif terhadap obesitas sebanyak $56,5 \%$ dari pada persepsi negatif, masih banyak responden yang meyakini obesitas bukanlah maslah pada anak (Tabel 2). Responden yang lebih banyak memiliki persepsi positif terhadap obesitas yaitu resonden dengan usia 20-29 tahun sebanyak $83,3 \%$ di bandingkan dengan responden yang berusia 30-39 tahun dan 40-50 tahun (Tabel 3). Responden yang memiliki persepsi positif terhadap obesitas yang paling banyak yaitu responden dengan pendidikan terakhir yaitu pendidikan dasar 
Tabel 2 Persepsi Ibu Terhadap Obesitas Pada Anak

\begin{tabular}{lc}
\hline Persepsi & Jumlah (\%) \\
\hline Positif & $52(56,5)$ \\
Negatif & $40(43,5)$ \\
\hline
\end{tabular}

Tabel 3 Distribusi Persepsi Responden Berdasarkan Usia

\begin{tabular}{lcc}
\hline & \multicolumn{3}{c}{ Persepsi } \\
\cline { 2 - 3 } Usia & Positif (\%) & Negatif (\%) \\
\hline 20-29 Tahun & $5(83,3)$ & $1(16,7)$ \\
30-39 Tahun & $24(41,4)$ & $34(58,6)$ \\
40-50 Tahun & $11(39,3)$ & $17(60,7)$ \\
\hline
\end{tabular}

Tabel 4 Distribusi Persepsi Respon den Berdasarkan Pendidikan

\begin{tabular}{lcc}
\hline & \multicolumn{2}{c}{ Persepsi } \\
\cline { 2 - 3 } Pendidikan & Positif (\%) & Negatif (\%) \\
\hline Pendidikan dasar & $13(72,2)$ & $5(27,8)$ \\
Pendidikan menengah & $22(40,7)$ & $32(59,3)$ \\
Pendidikan tinggi & $6(30,0)$ & $14(70,0)$ \\
\hline
\end{tabular}

Tabel 5 Distribusi Persepsi Responden Berdasarkan Status Pekerjaan

\begin{tabular}{lcc}
\hline & \multicolumn{2}{c}{ Persepsi } \\
\cline { 2 - 3 } Pekerjaan & Positif (\%) & Negatif (\%) \\
\hline Bekerja & $41(69,5)$ & $18(30,5)$ \\
Tidak bekerja & $16(48,5)$ & $17(51,5)$ \\
\hline
\end{tabular}

sebanyak $72,2 \%$ di bandingkan dengan responden yang berpendidikan menengah dan pendidikan tinggi (Tabel 4). Responden yang memiliki persepsi positif paling banyak yaitu responden yang bekerja sebanyak $69,5 \%$ di bandingkan dengan responden yang tidak bekerja (Tabel 5).

responden yang lebih banyak memiliki persepsi positif terhadap obesitas yaitu resonden dengan usia 20-29 tahun sebanyak 83,3\% di bandingkan dengan responden yang berusia 30-39 tahun dan 40-50 tahun

\section{PEMBAHASAN}

Berdasarkan hasil penelitian ini responden usia 20-29 tahun lebih banyak memiliki persepsi positif atau menganggap bahwa obesitas itu bagus untuk anak-anak. Memiliki persepsi bahwa berat badan lebih dalam hal ini gemuk bagus untuk anak sebanyak $83,3 \%$. Hal ini sesuai dengan penelitian yang dilakukan oleh Angga deni (2013) di mana dalam dalam hasil penelitiannya ibu usia 20-30 tahun lebih banyak memiliki persepsi bahwa obesitas pada anak adalah baik untuk anak sebanyak $57,14 \%$ di bandingkan dengan ibu yang memiliki usia lebih matang. ${ }^{11}$
Semakin bertambahya usia persepsi tenatang obesitas berubah, semakin tua usia ibu semakin banyak yang berpendapat bahwa obesitas tidak terlalu baik pada anak-anak, hal ini dilihat bahwa ibu-ibu muda lebih sering terpapar media yang sering kali memperlihatkan image tentang anak yang sehat itu adalah anak yang gemuk sehingga ibu-ibu mudah cepat terpengaruh, selain itu pengalaman mereka dalam mengasuh anak belum banyak sehingga gampang sekali dipengaruhi oleh media-media sosial. ${ }^{1}$

Berdasarkan hasil penelitian responden dengan pendidikan terakhir yaitu pendidikan dasar paling banyak memiliki persepsi positif atau menganggap bahwa obsitas pada anak itu bagus untuk anak sebanyak $72,2 \%$. Hal ini sesuai dengan penelitian yang dilakukan oleh Ratna (2015) di mana dalam hasil penelitiannya responden dengan pendidikan terakhir yaitu pendidikan dasar lebih banyak memiliki persepsi positif atau menganggap obesitas pada anak bukanlah masalah untuk anak yaitu sebanyak $75,0 \%$ di bandingkan dengan ibu yang perpendidikan lebih tinggi. ${ }^{10}$

Hal ini dimungkinkan karena responden yang mempunyai pendidikan terakhir yaitu pendidikan dasar menyebabkan responden dalam mempersepsikan sesuatu kurang tepat, karena tingkat pendidikan dasar hanya mempelajari yang umum saja, sehingga responden mempersepsikan obesitas pada anak sebagai hal yang baik. Dilihat bahwa semakin tinggi pendidikan sesorang semakin mudah untuk menerima informasi sehingga semakin banyak pengetahuan yang di dapatkan, sebaliknya pendidikan yang kurang akan menghambat perkembangan persepsi terhadap nilai-nilai yang baru di dapatkan. ${ }^{9}$

Berdasarkan hasil penelitian ini responden yang bekerja lebih banyak memiliki persepsi positif atau menganggap bahwa obesitas pada anak itu baik sebanyak $69,5 \%$. Hal ini sesuai dengan penelitian yang dilakukan oleh Ratna (2015) di mana pada penelitiannya responden dengan status pekerjaan yaitu bekerja lebih banyak memiliki persepsi positinf atau menggap obesitas bukanlah masalah pada anak sebanyak $71,4 \%$ di bandingkan dengan ibu yang tidak bekerja. ${ }^{10}$ Hal ini dikarenakan ibu yang sibuk bekerja di luar rumah cenderung lebih terfokus dengan pekerjaannya, sehingga dapat menyebabkan dampak negatif seperti stress, ketidakpuasan tidur dan ketegangan dalam keluarga karena itu akan mempengaruhi ibu dalam merawat anak.

\section{SIMPULAN}

Berdasarkan hasil studi ini, maka dapat disimpulkan bahwa persepsi ibu terhadap obesitas pada 
anak, maka dapat di simpulkan hasil bawha ibu lebih banyak memiliki persepsi positif, karena berdasarkan karakteristik ibu itu cendrung lebih banyak memiliki persepsi positif terhadap obesitas pada anak.

\section{KONFLIK KEPENTINGAN}

Penulis menyatakan tidak terdapat suatu konflik kepentingan terhadap publikasi dari artikel ini.

\section{PENDANAAN}

Penelitian ini tidak mendapatkan suatu pendanaan yang diberikan oleh pemerintah ataupun lembaga swasta lainnya.

\section{KONTRIBUSI PENULIS}

Konsep penelitian: Putu Eksa Bidja Yudha Putri, Komang ayu Kartika Sari, Luh Putu Ariastuti. Pengumpulan data, input data dan pengolahan data: Putu Eksa Bidja Yudha Putri. Penyusunan naskah Penelitian: Putu Eksa Bidja Yudha Putri.

\section{ETHICAL CLEARANCE NUMBER:}

1734/UN14.2.2/PD/KEP/2018.

\section{DAFTAR PUSTAKA}

1. Hidayati SN., Irawan R., Hidayat B. Obesitas Pada Anak. 2005. Tersedia di: Old. pediatrik .com/buletin/06224113652-048qwc.pdf.
2. Syarif DR. Chilhood obesity: Evaluation and management. Dalam Naskah lengkap national obesity symposium II. Surabaya. 2003. 123-139.

3. Riskesdas Provinsi Bali, 2013. Riset Kesehatan Dasar Dalam Angka. Tersedia di: http://www.diskes.baliprov.go.id/files/ subdomain/diskes/November\%202015/Riskesdas/riskesdas\%20bali\%202013.pdf [Diakes: 1 Desember 2017].

4. Vuorela N., Saha M. T., \& Salo MK. 2010. Parents underestimate their child's overwight. Acute Pediatrical, vol.99(9) 1374-1379.

5. World Health Organization. Fact Sheet Obesity and Overweight. 2014. Tersedia di: http:/www.who.int/ end-childhood-obesity/fact/en/. [Diakes: 30. November 2014].

6. Pakpour AH., Yekaninejad MS., \& Chen H. Mothers' perection of Obesity in schoolchildren: Jornal de Pediatrial. 2011. vol.87(2)169-74.

7. Golan M., \& Crow, S. Parents are Key Players in the Prevention and Treatment of Weight Related Problem. Nutrition Review. 2004. vol.62(1)39-50.

8. Pradnyandari P., Saraswati R. Gambaran Kebiasaan Mengonsumsi Makanan Cepat Saji Dan Obesitas Pada Mahasiswa Semester V Program Studi Kedokteran Umum Universitas Udayana tahun 2014. Intisari sains medis. 2015. 4(1): 6-13. Doi:10.15562/ism.v4i1.44.

9. Baughcum AE., Chamberlin LA., Deeks CM., Powers SW., \& Whitaker RC. Menernal Perceptions of Overweight. 2000.

10. Ratna S. Gambaran Persepsi Ibu Terhadap Obesita Pada Anak Usia Prasekolah Di Kelurahan Grogol Selatan Kebayoran Lama. Jakarta: Universitas Islam Negri (UNI) Syarif Hidayatullah. 2015

11. Angga DDT. Gambaran Persepsi Ibu tentang Obesitas pada Balita di Desa Ngudirejo Kecamatan Diwek Kabupaten Jombang. 2013.

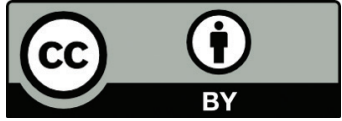

This work is licensed under a Creative Commons Attribution 